\title{
Pengaruh Faktor Penggunaan Lahan Terhadap Degradasi Lahan Akibat Erosi pada Hutan Primer dan Kebun Campuran Di Kecamatan Kairatu Kabupaten Seram Bagian Barat Propinsi Maluku
}

\author{
Silwanus M. Talakua \\ Jurusan Budidaya Pertanian, Fakultas Pertanian, Universitas Pattimura \\ Jl. Ir. M. Putuhena, Kampus Poka Ambon, 97233 \\ Email: nustalakua3165@gmail.com
}

\begin{abstract}
ABSTRAK
Penggunaan lahan merupakan faktor yang paling rentan dan selalu menjadi sasaran utama terhadap pengaruh perubahan oleh manusia dibandingkan dengan faktor lain, oleh karena itu sangat berpotensi terjadinya degradasi lahan akibat erosi. Tujuan penelitian adalah menguji pengaruh faktor penggunaan lahan antara lain luas penggunaan lahan, kerapatan vegetasi atas, kerapatan vegetasi bawah, serta faktor yang paling berpengaruh terhadap degradasi lahan akibat erosi pada hutan primer dan kebun campuran di Kecamatan Kairatu Kabupaten Seram Bagian Barat Provinsi Maluku. Metode yang digunakan adalah pengukuran indikator degradasi lahan di lapangan Hasil penelitian menunjukkan bahwa faktor luas penggunaan lahan berpengaruh nyata secara negatif terhadap degradasi lahan akibat erosi pada hutan primer $(\mathrm{P}=0,040 * ; \mathrm{r}=-0,71)$, sebaliknya pada kebun campuran, berpengaruh nyata secara positif $\left(\mathrm{P}=0,003^{*} ; \mathrm{r}=+0,86\right)$. Faktor kerapatan vegetasi atas berpengaruh nyata secara negatif terhadap pada hutan primer $\left(\mathrm{P}=0,006^{*}\right.$, dan $\left.\mathrm{r}=-0,82\right)$, maupun dan pada kebun campuran $\left(\mathrm{P}=0,002^{*} ; \mathrm{r}=-0,886\right)$. Faktor kerapatan vegetasi bawah berpengaruh nyata secara negatif pada hutan primer $\left(\mathrm{P}=0,020^{*} ; \mathrm{r}=-0,77\right)$, maupun pada kebun campuran $\left(\mathrm{P}=0,000^{*} ; \mathrm{r}=-0,92\right.$. Faktor yang paling berpengaruh nyata terhadap degradasi lahan akibat erosi pada penggunaan lahan hutan primer adalah kerapatan vegetasi $\left(\mathrm{P}_{\text {parsial } \mathrm{X} 2 \mathrm{HP}}=0,006^{*} ; \mathrm{R}^{2}=0,68\right)$. Faktor yang paling berpengaruh terhadap degradasi lahan akibat erosi pada penggunaan lahan kebun campuran adalah luas penggunaan lahan $\left(\mathrm{P}_{\text {parsial }}\right.$ $\mathrm{X} 1 \mathrm{KC} / \mathrm{P}=0,004 *)$ dan kerapatan vegetasi bawah $\left(\mathrm{P}_{\text {parsial } \mathrm{X} 3 \mathrm{KC} / \mathrm{P}}=0,042 *\right)$ dengan nilai $\mathrm{R}^{2}=0,88$.
\end{abstract}

Kata Kunci: degradasi lahan, erosi, kerapatan vegetasi, hutan primer dan kebun campuran

\section{The Effects of Land Use Factor on Land Degradation due to Erosion at Primary Forest and Mixed Plantation in The District of Kairatu West Seram Regency, Maluku Province}

\begin{abstract}
Land use is the most vulnerable factor and has always been the main target for the effects of change by humans compared to other factors, therefore it has the potential for land degradation due to erosion. The research purposes was to analyze the influence of land use factors including land use area, upper vegetation density, lower vegetation density, and the dominant factors that influenced of land degradation due to erosion in primary forest and mixed plantation in Kairatu Sub District, West Seram District, Maluku Province. The method used was the measurement of land degradation indicators in the field (field assessment). The results showed that the area of land use has a significant negative effect on land degradation due to erosion in primary forest $\left(\mathrm{P}=0.040^{*} ; \mathrm{r}=-0.71\right)$, and a significant positive effect $\left(\mathrm{P}=0.003^{*} ; \mathrm{r}=+0.86\right)$ in mixed plantation. The upper vegetation density factor has a significant negative effect in the primary forest $\left(\mathrm{P}=0.006^{*}\right.$, and $\left.\mathrm{r}=-0.82\right)$ and in the mixed plantation $\left(\mathrm{P}=0.002^{*}\right.$; $r=-0.886)$. The lower vegetation density factor has a significant negative effect both in primary forest $(P=0.020 ; r$ $=-0.77)$ and in the mixed plantation $\left(\mathrm{P}=0.000^{*} ; \mathrm{r}=-0.92\right.$. The dominant and most influence factors on land degradation due to erosion in the primary forest land use is the density of upper vegetation $\left(\mathrm{P}_{\text {parsial }} \mathrm{X} 2 \mathrm{HP}=0.006^{*} ; \mathrm{R}^{2}\right.$ $=0.68$, while in the mixed plantation is the area of land use $\left(\mathrm{P}_{\text {parsial } \mathrm{X} 1 \mathrm{KC} / \mathrm{P}}=0.004 *\right)$ and lower vegetation density $\left(\mathrm{P}_{\text {parsial } \mathrm{X} 3 \mathrm{KC} / \mathrm{P}}=0.042^{*}\right)$ with a value of $\mathrm{R}^{2}=0.88$.
\end{abstract}

Key words: Land degradation, erosion, density of vegetation, primary forest, mixed plantation. 


\section{PENDAHULUAN}

Penggunaan lahan merupakan istilah yang digunakan untuk menjelaskan peranan manusia dalam menggunakan lahan, atau tindakan-tindakan yang dengan segera memodifikasi atau mengubah penutup lahan, atau dengan kata lain pola penggunaan lahan merupakan pencerminan dari kegiatankegiatan manusia yang ada di atasnya. Penggunaan lahan dapat secara alamiah seperti hutan primer maupun yang terbentuk sebagai akibat intervensi manusia seperti hutan sekunder.

Hutan lebat terutama ditentukan oleh jenis tanaman hutan yang tampak sebagai hutan lebat, baik yang tumbuh secara alami ataupun yang dipelihara ${ }^{[1]}$. Sedangkan kebun campuran pada umumnya, pada bidang tanah ini tidak ada jaringan-jaringan pengairan. Kualitas cara bertani tidak begitu tinggi Jenis tanaman rupa-rupa dengan tidak jelas mana yang menonjol dan letaknya di luar pekarangan.

Hutan alam memiliki batasan yaitu peruntukan lahan ditetapkan sebagai kawasan hutan dan perkembangan vegetasi hutan sebagai habitat binatang-binatang hutan. Tujuan penggunaan lahan untuk wahana konservasi tanah dan air, media produksi komoditi hasil hutan dan pelestarian plasma nutfah. Jenis vegetasi penutup lahan bervariasi didominasi oleh vegetasi pepohonan [2]. Hutan tanaman memiliki batasan yaitu peruntukan lahan sebagai kawasan hutan tempat tumbuh dan berkembangnya vegetasi hutan yang dibudidayakan. Tujuan penggunaan lahan sebagai media produksi komoditi hasil hutan berupa kayu dan hasil sampingan. Jenis vegetasi penutup lahan terdiri dari jenis pepohonan sejenis.

Penggunaan lahan merupakan faktor yang paling rentan dan selalu menjadi sasaran utama terhadap pengaruh perubahan oleh manusia dibandingkan dengan faktor-faktor lain seperti iklim, tanah, dan topografi. Akibat dari adanya campur tangan manusia dalam perubahan tersebut, maka terbentuklah berbagai tipe penggunaan lahan antara lain: areal yang dilindungi seperti hutan primer dan sekunder; Apabila komponen penggunaan lahan berubah terutama penggunaan lahan hutan (deforestasi) maka akan terjadi perubahan ekosistem, yang berdampak pada perubahan siklus hidrologi. Perubahan siklus hidrologi mengakibatkan aliran permukaan lebih besar dari infiltrasi sehingga selanjutnya menyebabkan kerusakan tanah karena erosi air.

Menurut International Soil Reference and Information Centre/United Nations Environment Programme ISRIC/UNEP, tipe kerusakan lahan di Indonesia yang terbesar disebabkan oleh erosi air (80\%), sedangkan sisanya masing-masing oleh degradasi kimia sebesar $15 \%$ dan degradasi fisik sebesar $5 \%$. Apabila ditinjau dari aspek penyebabnya, maka di Indonesia penyebab kerusakan lahan yang terbesar adalah oleh deforestasi sebesar $63 \%$ dan sisanya oleh aktivitas pertanian sebesar $37 \%{ }^{[3]}$.

Lahan kritis untuk Kabupaten Maluku Tengah antara tahun 1987 sampai tahun 1989 terjadi peningkatan luas yaitu dari 19.045 ha menjadi 45.401 ha (bertambah sebesar 26.356 ha), sedangkan untuk Kecamatan Kairatu dan Piru yang di dalamnya terdapat daerah penelitian, luas lahan kritis bertambah dari 10.845 ha pada tahun 1987 menjadi 18.825 ha pada tahun 1989 atau mengalami peningkatan sebesar $73,6 \%{ }^{[4]}$.

Meningkatnya lahan kritis di Kecamatan Kairatu, mengindikasikan telah terjadi pengurangan luas penggunaan lahan hutan, karena dikonversi untuk penggunaan lahan kebun campuran/perkebunan, ladang, permukiman, serta munculnya lahan-lahan marginal seperti semak belukar dan alangalang, dengan tingkat kerapatan vegetasi atas dan kerapatan vegetasi bawah yang semakin berkurang.

Tujuan penelitian adalah menguji pengaruh faktor penggunaan lahan antara lain 
luas penggunaan lahan, kerapatan vegetasi atas, kerapatan vegetasi bawah, serta faktor yang paling berpengaruh terhadap degradasi lahan akibat erosi pada hutan primer dan kebun campuran di Kecamatan Kairatu Kabupaten Seram Bagian Barat Provinsi Maluku.

\section{BAHAN DAN METODE}

Penelitian ini dilaksanakan di Kecamatan Kairatu Kabupaten Seram Bagian Barat Propinsi Maluku dengan luas 12.685,81 ha dan secara geografis terletak pada $3^{\circ} 06^{\prime} 01^{\prime \prime}$ - 3'27'10" Lintang Selatan dan 128 $18^{\circ} 57^{\prime \prime}$ $128^{\circ} 42^{\prime} 05^{\prime \prime}$ Bujur Timur. Berlangsung dari tahun 2006 sampai tahun 2007 yang dimulai dengan pengumpulan data, observasi, penelitian lapangan, analisis laboratorium dan pengolahan data sampai penulisan laporan.

\section{Penentuan Titik Pengamatan}

Penentuan titik pengamatan pada lokasi penelitian dilakukan berdasarkan Peta Unit Lahan skala 1: 100.000. Pada penelitian ini dikaji efek luas penggunaan lahan $\left(\mathrm{X}_{1}\right)$, kerapatan vegetasi atas $\left(\mathrm{X}_{2}\right)$, dan kerapatan vegetasi bawah $\left(\mathrm{X}_{3}\right)$ terhadap degradasi tanah (Y), pada semak belukar dan hutan sekunder, oleh karena itu dibuat area pengamatan dengan mengelompokan unit-unit lahan yang memiliki penggunaan lahan yang berbeda tetapi memiliki kelas topografi dan jenis geologi, klasifikasi asosiasi tanah dan kelompok iklim yang sama, dengan jumlah area pengamatan (n) adalah 9 .

\section{Pengukuran Variabel-Variabel Penelitian}

Karakteritik penggunaan lahan dalam hal ini luas (X1), penyebaran vegetasi dan kerapatan vegetasi atas didapat dari hasil analisis penginderaan jauh citra satelit Landsat False Colour Composite TM Tahun 1992 dan False Colour Composite MSS Tahun 1990 oleh Dinas Kehutanan Propinsi Maluku [5], maupun hasil penelitian lapangan. Setelah ditentukan jenis penggunaan lahan dan penyebarannya, maka selanjutnya diukur masing-masing tipe penggunaan lahan sesuai titik pengamatan dengan menggunakan planimeter dalam satuan luas yaitu hektar (ha). Pengukuran variabel kerapatan vegetasi atas (X2) dan kerapatan vegetasi bawah (X3) pada penggunaan lahan kebun campuran dan semak belukar adalah sesuai titik pengamatan di lapangan yaitu dengan mengukur luas area penutupan tajuk untuk vegetasi bawah, kemudian dibandingkan terhadap luas area pengamatan, sehingga didapat persentasi tingkat kerapatan vegetasi atas dan bawah berdasarkan formula ${ }^{[6,7]}$. Pengukuran degradasi lahan akibat erosi berdasarkan panduan, sesuai jumlah titik pengamatan $[8,9,10]$.

\section{Analisis Laboratorium}

Untuk penentuan kerusakan tanah akibat erosi aktual melalui pengukuran indikator erosi tanah di lapangan, maka yang dianalisis adalah tekstur tanah (meliputi kandungan pasir kasar - pasir sangat halus, debu dan liat) (metode pipet), bobot isi tanah (metode gravimetri), C-organik (metode metode Walkley and Black) untuk penentuan kandungan bahan organik dan permeabilitas profil tanah yang dilaksanakan di Laboratorium Departemen Tanah dan Sumberdaya Lahan Fakultas Pertanian Institut Pertanian Bogor.

\section{Analisis Data}

Hubungan antara variabel-variabel $Y$ dan X pada tiap area pengamatan (unit lahan) di lokasi penelitian dapat dinyatakan dalam model regresi linier, non linier (berpangkat, eksponensial, logaritma, subordo kedua dan subordo ketiga), serta regresi berganda ${ }^{[11,12]}$. Untuk model regresi linier secara umum adalah $Y_{i}=\beta_{o}+\beta_{1} X_{i j}+\varepsilon_{i}$; Keterangan: $Y_{i}=$ Variabel terikat yaitu erosi tanah ( $\mathrm{t} / \mathrm{ha} / \mathrm{tahun})$. $\mathrm{X}_{\mathrm{ij}}=$ Variabel-variabel bebas yaitu: luas (ha), kerapatan vegetasi atas (\%), dan kerapatan vegetasi bawah (\%) pada hutan primer dan 
kebun campuran; $\beta_{1}=$ koefisien regresi; $\beta_{0}=$ koefisien intersep; $\varepsilon_{\mathrm{i}}=$ galat; $\mathrm{i}=\ldots 1,2$.

\section{HASIL DAN PEMBAHASAN}

\section{Pengaruh Faktor Luas Penggunaan Lahan terhadap Degradasi Lahan pada Hutan Primer dan Kebun Campuran}

Berdasarkan hasil penelitian dan hasil sidik ragam regresi ternyata bahwa luas penggunaan lahan berpengaruh nyata secara negatif terhadap degradasi lahan pada hutan primer, dengan nilai-P $=0,04^{*}$, koefisien determinasi $\left(\mathrm{R}^{2}\right)=0,476$, serta memiliki koefisien korelasi (r) negatif yaitu $-0,71$. Sebaliknya pada kebun campuran, luas penggunaan lahan berpengaruh nyata secara positif dengan nilai $\mathrm{P}=0,003^{*}$, koefisien determinasi $\left(\mathrm{R}^{2}\right)=0,740$ serta koefisien korelasi (r) positif yaitu 0,86 seperti disajikan pada Gambar 1. Dapat dijelaskan bahwa pada penggunaan lahan hutan alami seperti hutan primer, dengan semakin luas arealnya terpelihara maka akan menyebabkan kerusakan tanah akibat erosi makin berkurang. Semakin luas areal hutan berarti semakin banyak vegetasi yang berlapis-lapis baik pada tingkat pohon sampai penutup bawah, ini akan menyebabkan semakin tinggi tingkat perlindungan tanah terhadap pukulan butir hujan baik melalui tajuk tanaman, sumbangan lantai hutan maupun peranan zone perakaran vegetasi dalam mengikat agregat tanah. Oleh karena itu semakin luas hutan primer dan hutan sekunder maka degradasi tanah melalui peristiwa erosi semakin kecil.

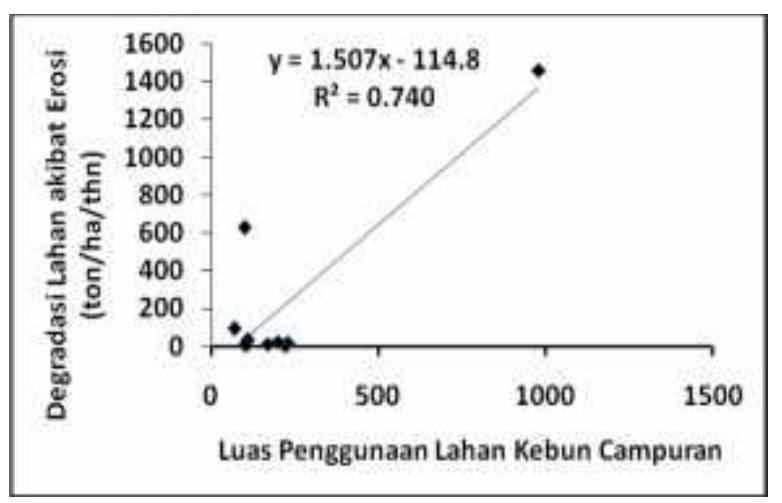

Gambar 1. Pengaruh luas penggunaan lahan terhadap degradasi lahan akibat erosi tanah pada penggunaan lahan hutan primer dan kebun campuran di Kecamatan Kairatu.

Sebaliknya penggunaan lahan kebun campuran merupakan penggunaan lahan hasil konversi dari areal hutan alami, menunjukkan bahwa semakin luas penggunaan lahan akan semakin meningkatkan degradasi lahan akibat erosi. Penggunaan lahan hasil konversi ini mempunyai kerapatan vegetasi dan stratifikasi vegetasi sangat kurang, demikian juga kerapatan vegetasi bawah relatif sangat kurang. Dengan kondisi seperti demikian hujan akan semakin besar langsung jatuh ke tanah dan sangat sedikit terintersep oleh tanaman atau vegetasi. Dengan demikian tingkat degradasi tanah jauh lebih besar dibandingkan dengan hutan primer.

Hal ini sesuai dengan hasil kajian penebangan hutan (deforestasi) menjadi penyebab meningkatnya laju aliran permukaan sejak vegetasinya dihilangkan ${ }^{[13]}$, dan jika konversi daerah berhutan menjadi lahan-lahan pertanian (perkebunan, kebun campuran, dan ladang), padang rumput atau permukiman penduduk mengakibatkan : (1) hilangnya biodiversitas, dan (2) terganggunya proses hidrologi, meningkatnya aliran permukaan dan menyebabkan peningkatan 
erosi dan banjir ${ }^{[14]}$. Makin meningkatnya luas hutan akan menurunkan degradasi tanah, sebaliknya peningkatan luas kebun campuran oleh petani cenderung meningkatkan degradasi tanah ${ }^{[21,22,25]}$.

\section{Pengaruh Faktor Kerapatan Vegetasi Atas terhadap Degradasi Tanah pada Penggunaan Lahan Hutan Primer dan Kebun Campuran}

Berdasarkan hasil penelitian dan hasil sidik ragam regresi ternyata bahwa kerapatan vegetasi atas berpengaruh nyata secara negatif terhadap degradasi lahan akibat erosi pada hutan primer, dengan nilai-P $=0,006^{*}$, koefisien determinasi $\left(\mathrm{R}^{2}\right)=0,677$, serta memiliki koefisien korelasi (r) negatif yaitu 0,82 . Begitu juga pada kebun campuran, kerapatan vegetasi atas berpengaruh nyata secara negatif dengan nilai $\mathrm{P}=0,002 *$, koefisien determinasi $\left(\mathrm{R}^{2}\right)=0,773$ serta koefisien korelasi (r) negatif yaitu $-0,886$ seperti disajikan pada Gambar 2.
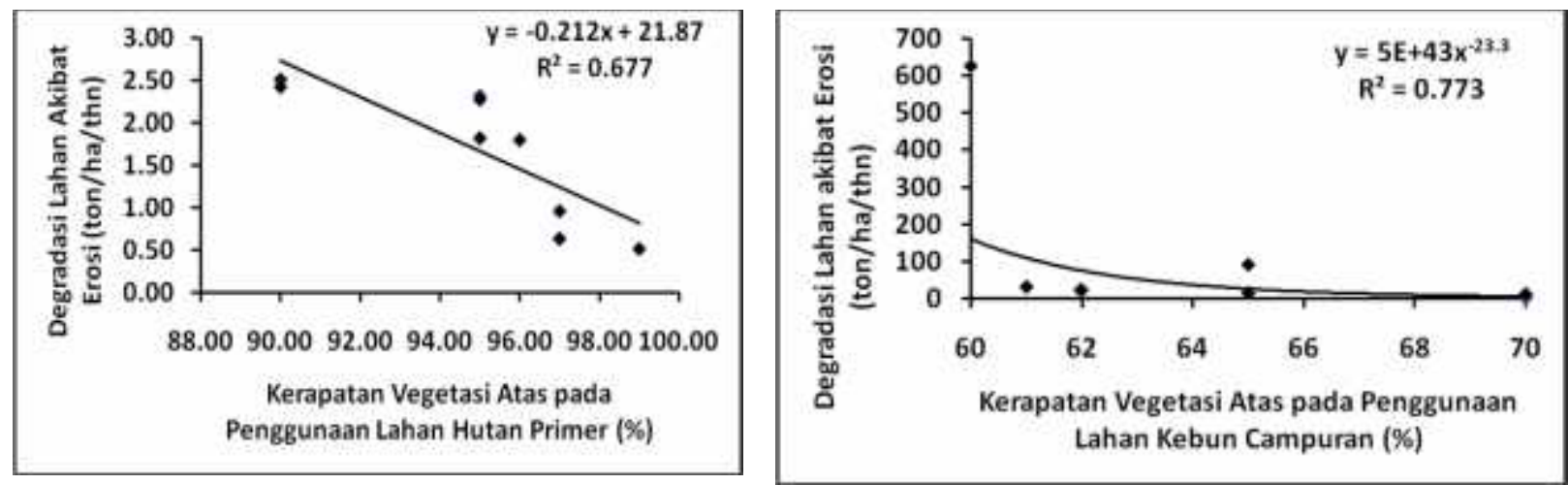

Gambar 2. Pengaruh kerapatan vegetasi atas terhadap erosi tanah pada penggunaan lahan hutan primer dan kebun campuran di Kecamatan Kairatu

Dari hasil tersebut dapat dilihat bahwa semakin berkurangnya kerapatan vegetasi atas akan menyebabkan degradasi lahan akibat erosi semakin meningkat pada hutan primer dan kebun campuran. Dapat dijelaskan bahwa adanya vegetasi yang sangat rapat, terutama strata atas dapat melindungi melalui tajuk vegetasinya yang mampu mengintersep sebagian besar curah hujan yang jatuh, sehingga yang jatuh langsung ke permukaan tanah sangat sedikit sekali dengan energi yang sudah sangat berkurang. Di samping itu juga adanya vegetasi yang semakin rapat pada permukaan tanah mampu memperkecil aliran permukaan dan memperbesar infiltrasi. Hal yang sama juga terjagi di Nepal, bahwa kerapatan vegetasi atas berpengaruh terhadap erosi tanah dimana makin berkurangnya kerapatan vegetasi atas maka erosi makin meningkat ${ }^{[15]}$. Dua komponen dari penutupan tajuk dalam mengurangi erosi yaitu penutup atas (aerial cover) dan penutup bawah (contact cover) ${ }^{[16]}$. Beberapa hasil penelitian menunjukkan bahwa meningkatnya kerapatan vegetasi atas pada hutan primer dan kebun campuran akan menurunkan tingkat degradasi tanah akibat erosi ${ }^{[9,21,22]}$. Hasil penelitian lainnya menunjukkan bahwa pada tingkat degradasi ringan, kondisi vegetasi umumnya masih baik, terutama kerapatan vegetasi atas dan bawah, serta stratifikasi vegetasinya masih tergolong tinggi seperti hutan primer. Pada kondisi ini, curah hujan yang jatuh dari atmosfer dengan energi erosivitas yang tinggi, mampu diintersep oleh kanopi atas, dan energi hujan akibat kecepatan terminal dan aliran permukaan mampu ditahan dan dikendalikan oleh vegetasi penutup bawah, 
sehingga permukaan tanah tetap terlindung secara baik dalam waktu yang relatif lama dibandingkan dengan penggunaan lahan lainnya ${ }^{[23,24]}$.

\section{Pengaruh Faktor Kerapatan Vegetasi Bawah Terhadap Degradasi Tanah pada Penggunaan Lahan Hutan Primer dan Kebun Campuran}

Berdasarkan hasil penelitian dan hasil sidik ragam regresi ternyata bahwa kerapatan vegetasi bawah berpengaruh nyata secara negatif terhadap degradasi lahan pada hutan primer, dengan nilai $\mathrm{P}=0,020^{*}$, koefisien determinasi $\left(R^{2}\right)=0,664$, serta memiliki koefisien korelasi (r) negatif yaitu -0,77. Begitu juga pada kebun campuran, kerapatan vegetasi atas berpengaruh nyata secara negatif dengan nilai $\mathrm{P}=0,000^{*}$, koefisien determinasi $\left(\mathrm{R}^{2}\right)=0,851$ serta koefisien korelasi (r) negatif yaitu $-0,92$ seperti disajikan pada Gambar 3.
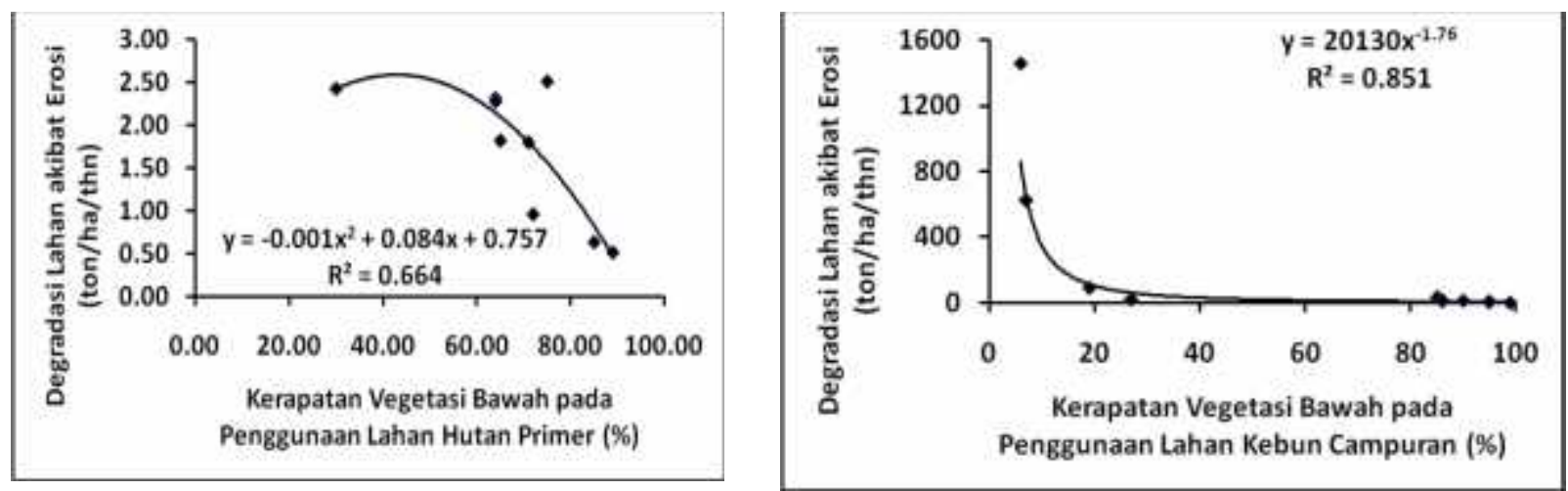

Gambar 3. Pengaruh kerapatan vegetasi bawah terhadap erosi tanah pada penggunaan lahan hutan primer dan kebun campuran di Kecamatan Kairatu.

Dari hasil tersebut dapat dilihat bahwa semakin berkurangnya kerapatan vegetasi bawah akan menyebabkan degradasi lahan akibat erosi semakin meningkat pada hutan primer dan kebun campuran. Dapat dijelaskan bahwa adanya vegetasi penutup bawah pada seluruh penggunaan lahan maka sangat berperan dalam mencegah erosi percikan dengan melindungi tanah dari dampak pukulan air hujan secara langsung, mengintersep curah hujan yang jatuh, mengurangi tingginya tetesan yang jatuh ke tanah yang pada dasarnya mengurangi dari kekuatan energi perusak.

Selain itu juga membantu terpeliharanya konsistensi laju infiltrasi tanah dan mencegah terbentuknya lapisan kerak di permukaan., mengurangi laju dan volume aliran permukaan dengan menahan sebagian dari air itu untuk penggunaannya sendiri, membantu pengikatan agregat tanah, memperbaiki struktur tanah dan porositas oleh bahan bahan organik. Hasil penelitian lainnya juga ditemukan bahwa kehilangan penutup tanah akan mengintensifkan kerusakan tanah khususnya pada lerenglereng curam, karena terjadi peningkatan erosi dan aliran permukaan yang ditunjukkan dengan adanya erosi alur dan parit yang sangat besar ${ }^{[17]}$. Kemampuan tetesan hujan di bawah pohon untuk mengerosi tanah lebih besar karena tetesan hujan mengumpul sebelum menetes dari dedaunan dan kemudian akan menghantam tanah dengan kekuatan yang lebih besar ${ }^{[18]}$. Meningkatnya kerapatan vegetasi bawah atas pada hutan primer dan kebun campuran akan menurunkan tingkat degradasi tanah akibat erosi ${ }^{[9,21,22]}$, demikian juga pada tingkat degradasi ringan, kondisi vegetasi umumnya 
masih baik, terutama kerapatan vegetasi atas dan bawah, serta stratifikasi vegetasinya masih tergolong tinggi seperti hutan primer ${ }^{[23,24]}$. Pada kondisi ini, curah hujan yang jatuh dari atmosfer dengan energi erosivitas yang tinggi, mampu diintersep oleh kanopi atas, dan energi hujan akibat kecepatan terminal dan aliran permukaan mampu ditahan dan dikendalikan oleh vegetasi penutup bawah, sehingga permukaan tanah tetap terlindung secara baik dalam waktu yang relatif lama dibandingkan dengan penggunaan lahan lainnya.

\section{Pengaruh Faktor Penggunaan Lahan: Luas, Kerapatan Vegetasi Atas dan Kerapatan Vegetasi Bawah serta Faktor yang paling berpengaruh Terhadap Degradasi Lahan akibat Erosi pada Hutan Primer dan Kebun Campuran}

Berdasarkan hasil dan analisis regresi pada penggunaan lahan hutan primer, ternyata bahwa luas penggunaan lahan $\left(\mathrm{X}_{1 \mathrm{HP}}\right)$, kerapatan vegetasi atas $\left(\mathrm{X}_{2 \mathrm{HP}}\right)$ dan kerapatan vegetasi bawah $\left(\mathrm{X}_{3 \mathrm{HP}}\right)$ berpengaruh nyata $(\mathrm{P}$ $=0,037)$ terhadap kerusakan tanah $\left(\mathrm{Y}_{\mathrm{HP}}\right)$ dengan koefisien determinasi $\mathrm{R}^{2}=0,79$, dan persamaan regresinya adalah : $\mathrm{Y}_{\mathrm{HP}}=17,9-$ $0,000416 \mathrm{X}_{1 \mathrm{HP}}-0,168 \mathrm{X}_{2 \mathrm{HP}}-0,0005 \mathrm{X}_{3 \mathrm{HP}}$. Hal ini menunjukkan bahwa dengan semakin berkurangnya luas penggunaan lahan, berkurangnya kerapatan vegetasi atas dan berkurangnya kerapatan vegetasi bawah pada hutan primer maka degradasi lahan akibat erosi pada penggunaan lahan ini semakin meningkat.

Setelah dilakukan uji regresi parsial terbaik (step wise/ best subset) terhadap semua variabel $\mathrm{X}$, maka variabel kerapatan vegetasi atas sangat nyata $\left(\mathrm{P}_{\text {parsial }} \mathrm{X} 2 \mathrm{HP}=\right.$ 0,006) berpengaruh terhadap degradasi lahan akibat erosi ( $\left.\mathrm{Y}_{\mathrm{HP}}\right)$ dengan koefisien determinasi $\mathrm{R}^{2}=0,68$ dan persamaan regresinya adalah: $\mathrm{Y}_{\mathrm{HP}}=21,9-0,213 \mathrm{X}_{2 \mathrm{HP}}$. Hal ini menunjukkan bahwa dengan semakin rendahnya tingkat kerapatan vegetasi atas pada hutan primer maka degradasi lahan akibat erosi semakin meningkat. Dapat dijelaskan bahwa vegetasi hutan primer dan hutan sekunder memiliki kanopi rapat dan serasah bawah/mulsa yang tebal yang dapat berfungsi untuk mengintersep air hujan yang dapat menyebabkan erosi percikan, maupun aliran permukaan yang pada akhirnya akan menurunkan erosi. Struktur vegetasi sangat berpengaruh terhadap bahaya erosi dimana struktur yang bertingkat-tingkat dapat menurunkan bahaya erosi ${ }^{[19]}$. Hasil penelitian di Lampung ditemukan bahwa penutupan lahan terutama dengan adanya kanopi tanaman hutan yang rapat menyebabkan erosi di kawasan hutan alam relatif lebih rendah dibandingkan dengan kebun ${ }^{[20]}$.

Berdasarkan hasil penelitian dan hasil uji regresi pada penggunaan lahan kebun campuran/ perkebunan, ternyata bahwa luas penggunaan lahan $\left(\mathrm{X}_{1 \mathrm{KC} / \mathrm{P}}\right)$, kerapatan vegetasi atas $\left(\mathrm{X}_{2 \mathrm{KC} / \mathrm{P}}\right)$ dan kerapatan vegetasi bawah $\left(\mathrm{X}_{3 \mathrm{KC} / \mathrm{P}}\right)$ berpengaruh sangat nyata $(\mathrm{P}=$ $0,009)$ terhadap degradasi lahan akibat erosi $\left(\mathrm{Y}_{\mathrm{KC} / \mathrm{P}}\right)$ dengan koefisien determinasi $\mathrm{R}^{2}=$ 0,88 dan persamaan regresinya adalah: $\mathrm{Y}_{\mathrm{KC} / \mathrm{P}}$ $=1063+1,15 \mathrm{X}_{1 \mathrm{KC} / \mathrm{P}}-13,6 \mathrm{X}_{2 \mathrm{KC} / \mathrm{P}}-$

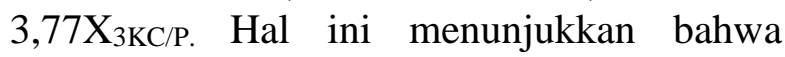
dengan semakin meningkat luas penggunaan lahan, berkurangnya kerapatan vegetasi atas dan berkurangnya kerapatan vegetasi bawah pada kebun campuran/perkebunan maka degradasi lahan akibat erosi semakin meningkat.

Hasil uji regresi parsial terbaik (step wise/best subset) terhadap semua variabel $\mathrm{X}$, luas penggunaan lahan $\left(\mathrm{X}_{1 \mathrm{KC} / \mathrm{P}}\right)$ berpengaruh sangat nyata $\left(\mathrm{P}_{\text {parsial } \mathrm{X} 1 \mathrm{KC} / \mathrm{P}}=0,004\right)$ terhadap kerusakan tanah, sedangkan variabel kerapatan vegetasi bawah $\left(\mathrm{X}_{3 \mathrm{KC} / \mathrm{P}}\right)$ berpengaruh nyata $\left(\mathrm{P}_{\text {parsial }} \mathrm{X3KC/ \textrm {P }}=0,042\right)$ terhadap kerusakan tanah $\left(\mathrm{Y}_{\mathrm{KC} / \mathrm{P}}\right)$ dengan koefisien determinasi $\mathrm{R}^{2}=0,88$ dan persamaan regresinya adalah : $\mathrm{Y}_{\mathrm{KC} / \mathrm{P}}=225,3$ $+1,24 \mathrm{X}_{1 \mathrm{KC} / \mathrm{P}}-4,8 \mathrm{X}_{3 \mathrm{KC} / \mathrm{P} \text {. Hal ini }}$ menunjukkan bahwa variabel luas penggunaan lahan dan kerapatan vegetasi bawah merupakan faktor yang paling berpengaruh terhadap degradasi lahan akibat 
erosi pada kebun campuran/perkebunan. Hal ini dapat dijelaskan bahwa pada daerah penelitian telah terjadi perluasan areal untuk kebun campuran dan perkebunan kakao, dan sebagian besar permukaan tanahnya telah dibersihkan dari vegetasi bawah, sehingga terjadi peningkatan erosi diikuti dengan munculnya pedestal, akar terekpos, alur dan parit. Ini berarti bahwa dengan makin meluasnya areal kebun campuran/perkebunan dan semakin rendahnya kerapatan vegetasi bawah, maka tingkat kerusakan tanah karena erosi semakin meningkat.

Beberapa hasil penelitian sebelumnya menunjukkan hal yang sama bahwa pada lahan-lahan perkebunan yang tanahnya telah dibersihkan dari vegetasi dan humus akan mengalami masalah erosi yang serius [18]. Konversi daerah berhutan menjadi lahanlahan pertanian dalam hal ini perkebunan dan kebun campuran akan mengakibatkan terganggunya proses hidrologi, meningkatnya aliran permukaan dan menyebabkan peningkatan erosi [14]. Meningkatnya luas penggunaan lahan dan berkurangnya kerapatan vegetasi bawah pada kebun campuran akan menurunkan tingkat degradasi tanah akibat erosi ${ }^{[9,21,22] \text {. }}$

\section{KESIMPULAN}

Berdasarkan hasil penelitian disimbukan bahwa :

- Faktor luas penggunaan lahan berpengaruh nyata secara negatif terhadap degradasi lahan akibat erosi pada hutan primer $\left(P=0,040^{*} ; R^{2}=0,476 ; r=-0,71\right.$. Sebaliknya pada kebun campuran, berpengaruh positif $\left(\mathrm{P}=0,003^{*} ; \mathrm{R}^{2}=\right.$ 0,$740 ; r=+0,86$ ).

- Faktor kerapatan vegetasi atas berpengaruh nyata secara negatif terhadap degradasi lahan akibat erosi pada hutan primer, $(\mathrm{P}=$ $0,006^{*} ; R^{2}=0,677 ; r=-0,82$. Begitu juga pada kebun campuran, berpengaruh nyata secara negatif $\left(P=0,002^{*} ; R^{2}=0,773 ; r=\right.$ $-0,886$.

- Faktor kerapatan vegetasi bawah berpengaruh nyata secara negatif terhadap degradasi lahan akibat erosi pada hutan primer $\left(\mathrm{P}=0,020^{*} ; \mathrm{R}^{2}=0,664 ; \mathrm{r}=-0,77\right.$. Begitu juga pada kebun campuran, berpengaruh nyata secara negative $(\mathrm{P}=$ $0,000 * ; R^{2}=0,851 ; r=-0,92$.

- Faktor yang paling berpengaruh nyata terhadap degradasi lahan akibat erosi pada penggunaan lahan hutan primer adalah kerapatan vegetasi atas $\left(\mathrm{P}_{\text {parsial }} \mathrm{X} 2 \mathrm{HP}=\right.$ 0,006); $\mathrm{R}^{2}=0,68$ dan persamaan regresinya adalah: $Y_{H P}=21,9-0,213 X_{2 H P}$.

- Faktor yang paling berpengaruh nyata terhadap degradasi lahan akibat erosi pada penggunaan lahan kebun campuran adalah luas penggunaan lahan $\left(\mathrm{P}_{\text {parsial }} \mathrm{X} 1 \mathrm{KC} / \mathrm{P}=\right.$ 0,004) dan kerapatan vegetasi bawah $\left(\mathrm{P}_{\text {parsial }} \mathrm{X} 3 \mathrm{KC} / \mathrm{P}=0,042\right) ; \mathrm{R}^{2}=0,88$ dan persamaan regresinya adalah : $\mathrm{Y}_{\mathrm{KC} / \mathrm{P}}=$ $225,3+1,24 \mathrm{X}_{1 \mathrm{KC} / \mathrm{P}}-4,8 \mathrm{X}_{3 \mathrm{KC} / \mathrm{P} \text {. }}$

\section{DAFTAR PUSTAKA}

[1] Sandy. I.M. 1977. Penggunaan Tanah (land use) di IndonesiaPublikasi No. 75 Direktorat Tata Guna Tanah. Departemen Dalam Negeri. Jakarta

[2] FAO. 1995. Global and National Soils and Terrain Digital Databases (SOTER). Prosedures Manual. Land and Water Development Devision. World Soil Resources Reports No. 74 Rev.1

[3] FAO. 1996. Population ChangeNatural Resources- Environment Linkages In East and Southeast Asia. Prepared by the Population Information Network (POPIN) of the United Nations Population Division, Department for Economic and Social Information and Policy Analysis. FAO Population Programme Service, Rome.

[4] Badan Perencanaan Pembangunan Daerah (Bappeda) Propinsi Maluku. 
1996. Rencana Struktur Tata Ruang Propinsi Daerah Tingkat I Maluku. Fakta dan Analisis.

[5] Dinas Kehutanan Propinsi Maluku. 1994b. Peta Penggunaan Lahan Pulau Seram Propinsi Maluku skala 1 : 100.000. Sebagai Hasil Penafsiran Citra Satelit (Citra Landsat False Colour Composite TM Tahun 1992 dan False Colour Composite MSS Tahun 1990).

[6] Swiecki, T. J and E.A. Bernhardt. 2001. Guidelines for Developing and Evaluating Tree Ordinances. USDA Forest Service through the National Urban and Community Forestry Advisory Council and the International Society of Arboriculture.

[7] Dissmeyer G.E and G.R. Foster. 1980. A Guide For Predicting Sheet and Rill Erosion on Forest Land. USDA Forest Service Southeastern Area 1720 Peachtree Road, N.W. Atlanta, Gorgia 30367.

[8] Stocking. M and N. Murnaghan, 2000. Land Degradation Guidelines For Field Assessment. Overseas Development Group University of East Anglia Norwich,UK Co-operating Institutions : United Nations Environment Programme (UNEP), United Nations University (UNU). People, Land Management and Environmental Change Project (PLEC)Japan.

[9] Talakua, S.M. 2009. Pengaruh Penggunaan Lahan Terhadap Kerusakan Tanah Karena Erosi di Kecamatan Kairatu Kabupaten Seram Bagian Barat Provinsi Maluku. Jurnal Budidaya Pertanian 5 (1): (hal: 27-34)

[10] Talakua S.M. 2016. Degradasi Lahan Metode Analisis dan Aplikasinya dalam Penggunaan Lahan. Plantaxia. Ruko Jambusari 7A Yogyakarta 55283. ISBN:978-602-6912-13-8.

[11] Morrison D.F. 1976 Multivariate Statistical Methods. Second Edition.
Mc.Graw-Hill Book Company. New York St. Louis San Francisco Auckland Düsseldorf Johannesburg Kulala Lumpur London Mexico Montreal New Delhi Panama paris São Paulo Singapore Sydney Tokyo Toronto.

[12] Draper. N.R. dan H. Smith. 1992. Terjemahan Analisis Regresi Terapan. P.T. Gramedia Pustaka Utama. Jakarta.

[13] Symeonakis. E, S. Koukoulas, A. Calvo-Cases, E. Arnau-Rosalen and I. Makris. 2004. A Landuse Change and Land Degradation Study In Spain and Greece Using Remote Sensing and GIS. Departamento de Geografía, Universidad de Valencia, Av. Blasco Ibáñez 28, Valencia 46010, Spain Dept. of Geography, University of the Aegean, Mytilene 81100, Greece.

[14] Sherbinin. 2002. Guide to Land-Use and Land-Cover Change (LUCC) Center for International Earth Science Information Network (CIESIN) Columbia University Palisades, NY, USA. A collaborative effort of SEDAC and the IGBP/IHDP LUCC Project.

[15] Kokh and Shrestha. 2002. Soil Erosion Modelling Using Remote Sensing and GIS: A Case Study of Jhikhu Khola Watershed, Nepal. Part of aM. Tech. Thesis Submitted to Andhra University.

[16] FAO 1999. New Concepts and Approaches to Land Management in The Tropics with Emphasis on Steeplands. FAO Soil Bulletin 75. Land and Water Publication Series. Land and Water Development Devision.

[17] FAO 1999. Methods and Materials in Soil Conservation A Manual. Miscellaneous Reports/Guides/ Manuals/Filmstrips - Soil. Land and Water Publication Series. Land and Water Development Devision.

[18] FAO dan CIFOR. 2005. Hutan dan Banjir. Tenggelam Dalam Suatu Fiksi Atau Berkembang Dalam Fakta. RAP Publication 2005/3. Forest Perspective 2. Food and Agriculture Organization - 
Talakua S.M, 2020. Pengaruh Faktor Penggunaan Lahan ...

Centre of International Forestry Research.

[19] Asdak. C. 2002. Hidrologi dan Pengelolaan Daerah Aliran Sungai. Gadja Mada University Press.

[20] Sihite. J. 2001. Evaluasi Dampak Erosi Tanah Model Pendekatan Ekonomi Lingkungan dalam Perlindungan DAS : Kasus Sub-DAS Besai - DAS Tulang Bawang, Lampung. Disertasi Doktor Program Pascasarjana Institut Pertanian Bogor. ICRAF SE-Asia Southeast Asian Regional Research Programme PO Box 161 Bogor 16001 Indonesia.

[21] Talakua S.M. 2016. Identifikasi Degradasi Tanah dan Pengaruh Faktor Penggunaan Lahan Terhadap Degradasi Tanah pada Kebun Campuran dan Semak Belukar di Kecamatan Kairatu Kabupaten Seram Bagian Barat Provinsi Maluku. Jurnal Budidaya Pertanian Vol. 12(2):101-107.

[22] Talakua S.M. dan Osok. 2018. Efek Penggunaan Lahan Terhadap Degredasi Tanah pada Kebun Campuran di Kecamatan Kairatu Kabupaten Seram Bagian Barat Provinsi Maluku. Jurnal Agrologia 7 (1): 9-16.

[23] Talakua S.M. dan R.M. Osok 2017. Pengembangan Model Penilaian
Degradasi Lahan Berdasarkan Pendekatan Field Assessment. Studi Kasus Sub Daerah Aliran Sungai (DAS) Wae Sari DAS Wae Riuapa Kecamatan Kairatu Kabupaten Seram Bagian Barat Provinsi Maluku. Pattimura University Press. ISBN: 978-602-50112-2-1.

[24] Talakua S.M. dan R.M. Osok 2019. Development of Land Degradation Asessment Model Based on Field Indicators Assessment and Prediction Methods In Wai Sari Sub Watershed Kairatu District. Western Seram Regency. Maluku Province. Indonesia. Science Nature Journal. Faculty of Mathematics and Natural Sciences. Pattimura University. 2 (1): (page : 071085).

[25] Talakua S.M. 2008. Pengaruh Faktor Penggunaan Lahan, Kerapatan Vegetasi Atas, Kerapatan Vegetasi Bawah Terhadap Erosi pada Hutan Primer dan Hutan Sekunder di Kecamatan Kairatu Kabupaten Seram Bagian Barat Provinsi Maluku. Jurnal Makila. Jurnal Penelitian Kehutanan Volume II, Nomor 1, Tahun 2008. Hal 35-45. ISSN : 1978-4996 